\title{
How the measurement of residual volume developed after Davy (1800)
}

\author{
J-C. Yernault*, N. Pride**, G. Laszlo $\#$
}

\begin{abstract}
How the measurement of residual volume developed after Davy (1800). J-C. Yernault, N. Pride, G. Laszlo. C) ERS Journals Ltd 2000.

ABSTRACT: H. Davy measured the residual volume of his own lungs in 1800, by inhaling a hydrogen mixture contained in a mercurial air holder. Using the same principle, Nestor Gréhant determined the functional residual capacity, and the volume of the dead space, in 1864. Both used a forced breathing method, that was substituted by a prolonged dilution method by D.D. Van Slyke and C.A.L. Binger in 1923. It was in 1941 that G.R. Meneely and M.L. Kaltreider replaced hydrogen with helium. The open circuit nitrogen washout method was proposed by R.E. Darling, A. Cournand and D.W. Richards in 1940, and the body plethysmograph by A.B. DuBois et al. in 1956. So the three methods, still in common use today for measuring the static lung volumes, had been described by the mid-1950s.

Eur Respir J 2000; 16: 561-564.
\end{abstract}

*Dept of Thoracic Medicine, Hôpital Erasme, Brussels. **Thoracic Medicine, National Heart and Lung Institute, Dovehouse Street, London UK, ${ }^{\#}$ Respiratory Medicine, Bristol Royal Infirmary, Bristol, UK.

Correspondence: J-C. Yernault, Dept of Thoracic Medicine, Hôpital Erasme, B1070, Brussels. Fax: 3225554405.

\section{Keywords: Davy}

Grehant

history of medicine

residual volume

Received: May 52000

Accepted May 122000
Two hundred years has just elapsed since H. Davy measured the volume of residual gas remaining in his own lungs after a forced expiration, as well as their volume in a state of voluntary inspiration [1]. The idea that the lungs still contained air at the end of a full expiration was, according to Korns [2], advanced by BorelLi [3] in 1680. D.A. Borelli should be remembered as one of the first modern respiratory physiologists, when he stated that inspiration is accomplished by muscular action and expiration simply by muscular relaxation, and that the lungs themselves are purely passive. In the eighteenth century, several workers had attempted to measure the postmortem volume of the lungs. For instance GoodwYN [4] in 1788 (quoted by LUNDSGAARD, [5]), compressing the lungs by filling the pleural cavities with water, the diaphragm being fixed, provided an estimate of $1,800 \mathrm{~mL}$ for the quantity of air still present after a complete expiration. The first in vivo measurement is however attributable to H. Davy.

H. Davy was born at Penzance in Cornwall, UK on 17 December, 1778 , in a family that did not have sufficient means to permit him to attend university [6]. After a formal education that ceased in December, 1793, Davy became apprenticed to a surgeon-apothecary; however, more attention was paid to philosophy and mathematics by Davy than to physics. Davy's curiosity was aroused by S.L. Mitchill's writings on nitrous oxide $[7,8]$ and in 1797 Davy began preparing gases in his bedroom. He received a copy of T. Beddoes' work on factitious air from D. Giddy, who introduced him to T. Beddoes $[9,10]$. The latter recruited Davy as superintendent of the Pneumatic Institution, Bristol, UK which opened in 1798 , to take charge of the studies on gases and their possible therapeutic effects. On April 17, 1799, Davy inhaled $\mathrm{N}_{2} \mathrm{O}$, having first exhausted his lungs and occluded his nose, and experienced great exhilaration and a pleasurable sensation [6].

While investigating $\mathrm{N}_{2} \mathrm{O}$ uptake, Davy needed to know the residual volume of the lungs and designed the method of hydrogen dilution for this purpose, the results of which were published in 1800 [1]. This development was based on the following hypothesis: "as most gases, though of different specific gravities, when brought in contact with each other, form some sort of union, it is more than probable, that gas inspired into the lungs, from being placed in contact with the residual gas on such an extensive surface must instantly mingle with it. Hence, possibly one deep inspiration and complete expiration of the whole of one quantity of hydrogen, will be sufficient to determine the capacity of the lungs after complete voluntary exhaustion, and the nature of the residual air". Davy conducted the experiment as follows: "after a complete exhaustion of my lungs in the usual posture, I respired from a large mercurial air holder 102 cubic inches $[\sim 1670 \mathrm{~mL}]$ of hydrogen apparently pure at $59^{\circ}$ [Farhenheit] for rather less than a minute, making in this time 7 quick respirations". He measured the proportion of hydrogen remaining in the airholder "by inflammation with atmospheric air or oxygen of the detonating tube by the electric spark".

Davy had devised both the method of preparation and of measurement of the hydrogen concentration, and checked for the purity of the inhaled mixture [11]. Because there was virtually no difference between inspired and expired volumes during the respiration of hydrogen (the expired 
volume was 103 cubic inches in the experiment), Davy concluded that the gas was not absorbed and hypothesized that the air in the reservoir was of the same composition as the gas in the lung. He calculated, in a specific experiment, that the residual gas in the lung was 31.8 cubic inches; after correction for the difference in temperature between the air holder and the lung, the residual gas was estimated at 37.5 cubic inches. The experiments were not without side effects: "I found great difficulty in breathing hydrogen for so long as half a minute, so as to make a complete expiration of it. It produced uneasy feelings in the chest, momentary loss of muscular power and sometimes transient giddiness. In some of the experiments I made, on account of the giddiness, the results were rendered inconclusive by my removing my mouth from the mouthpiece after expiration, before the assistant could turn the stopcock". After a few repeated measurements, H. Davy estimated the volume of his lungs to be around $670 \mathrm{~mL}$ in a state of forced expiration and 4,160 $\mathrm{mL}$ in a state of voluntary inspiration. However, he realized that "his capacity was most probably below the medium, because his chest was narrow, measuring in circumference but 29 inches, and his neck rather long and slender".

Publication of Davy's researches into $\mathrm{N}_{2} \mathrm{O}$ led, late in 1800 , to an invitation to lecture at the Royal Institution in London [12], which ended his brief spell in respiratory physiology, but led to fame based on his chemical discoveries in the next few years. In 1815 Davy also invented the safety lamp for coal miners [13], and became President of the Royal Society in 1820, after which he travelled widely, and died in Geneva on May 29, 1829 [6].

According to HuTCHINSON [14] in 1846, further attempts to measure the residual air in the early nineteenth century yielded confusing views, with estimates 40-220 cubic inches $(650-3600 \mathrm{~mL})$. Hutchinson [14] called residual air the amount remaining in the lungs after they have been emptied by the most violent effort. However, he did not report himself on the residual air, but concentrated on the vital capacity, that he defined as the greatest voluntary expiration following the deepest inspiration, and divided into three parts: 1) the reserve air, that portion remaining in the lungs after the gentle expiration, which may be thrown out if required; 2) the breathing air, that portion required to perform the ordinary gentle inspiration and expiration; 3) the complemental air, that portion which can, at will, be drawn into the lungs by a violent exertion (beyond the moderate effort of ordinary breathing).

In his medical thesis published in 1864, GRÉHANT [15] stated that the volume of air contained in the lungs at the end of an expiration had only been measured postmortem, after fixation at the trachea of a pipe also attached to a bell filled with water. Although he did not mention H. Davy's work, he also proposed to inhale hydrogen to determine the volume of the lung, for at least 3 reasons: 1) According to SÉGUIN and LAVOISIER [16], hydrogen does not exert any noxious effect on the lung. They had shown that guinea pigs can stay in an atmosphere containing hydrogen and oxygen ("l'air vital") in proportion to that existing between oxygen and nitrogen in the atmospheric air for $8-10 \mathrm{~h}$. In addition the hydrogen concentration had not decreased at the end of the experiment, which meant that it left the lungs as it entered them. However it was ne- cessary to absorb carbon dioxide during the experiments. 2) Regnault and Reiset [17] have confirmed that little hydrogen could be absorbed through the lungs. 3) Free hydrogen is not present in the pulmonary tract, and during respiration it behaves like nitrogen.

GRÉHANT [14] introduced $1 \mathrm{~L}$ of hydrogen into a 3-4 L bell full of water, having at its upper part a tap connected to a glass pipe through a rubber tube. The subject to be examined put the pipe in his mouth, with his lips squeezed around, and closed also his nostrils. At the end of a normal expiration, he was connected to the container and inspired and expired 4-5 times consecutively. After the fifth expiration, the tap was closed and the volume of hydrogen present in the container was measured with an eudiometer. That volume of gas remaining in the lungs after a normal expiration was called the pulmonary capacity ("capacité pulmonaire"). In a group of 13 persons aged 17-35 yrs, it was estimated (after correction for temperature) to vary $2.19-3.22 \mathrm{~L}$. N. Gréhant also estimated the dead space ("l'air nuisible") around $170 \mathrm{~mL}$, and calculated the coefficient of ventilation, the ratio between the volume of "pure air" (the tidal volume minus the dead space) and the pulmonary capacity.

$\mathrm{N}$. Gréhant was concerned that his method could be dangerous because of a possible explosion of the hydrogen mixture, and also because the purity of hydrogen was not guaranteed. Combined with some residual arsenic, it yields a very toxic mixture, which even killed the chemist Gehlen! Both DAVY [1] and GRÉHANT [15] used the same technique (a forced breathing of an external gas), the first to measure the residual air (now called the residual volume), and the second the pulmonary capacity (now the functional residual capacity).

BERENSTEIN [18], reviewing in 1891 previous literature, noticed that extremes of measurements of residual air published varied 500-19,800 cubic centimeters. His own values in males varied 440-1250 ccm. BERENSTEIN [18] emphasized that the residual air was determined by the strength of the respiratory muscles and by the elasticity of the thoracic wall and of the lungs (a very modern view indeed!). He also noticed that the residual air of females was lower than that of males. In his thesis [19, 20], M. Berenstein showed how the determination of the residual air could be used as a diagnostic test for emphysema [21]. That an increased residual volume is a characteristic of emphysema was supported by several investigators over the first half of the twentieth century, and by BALDwIN et al. [22] in 1949 in their large series of 123 cases of "pulmonary emphysema".

At the end of the nineteenth century, several scientists tried to measure residual volume making use of Boyle's law [23]. Pflüger [24] with the "Pneumonometer", an early body plethysmograph, reported in 1882 values 400 $800 \mathrm{~mL}$. These attempts were criticized by CHRISTIE [25] and they did not reach a clinical application until 1956 [26].

DURIG [27] in 1903 proposed to abandon the breathing of hydrogen: he connected his subjects after a complete expiration to pure oxygen, and used the dilution of alveolar nitrogen as the indicator gas instead of the addition of hydrogen.

In the late nineteenth century and the early years of the twentieth century, physiologists started to study the relationships between the residual air and anthropometric data 
the first rough estimates being due to SCHENCK [28, 29] in 1894. A significant advance was made, when BoHR [30] started to measure the entire lung volume, with all its components on one and the same individual (according to Hasselbach [31] and Birath [32] he was the first); in addition $\mathrm{C}$. Bohr put more stress on the relationship between the "residual air" and the "total lung volume", than on their absolute values.

It was in 1923 that van SLYKe and Binger [33] substituted a dilution method without forced breathing to the early forced breathing method. They connected the subject at the end of a normal expiration to a spirometer containing a known volume of hydrogen, and allowed him to breathe normally for 5-6 min. They calculated the functional residual air by measuring the ratio between hydrogen and nitrogen. ANTHONY [34] arrived at satisfactory results using only hydrogen analysis carried out electromechanically according to KNIPPING [35]. CHRISTIE [25] in 1932 proposed a simple oxygen dilution method also without forced breathing, based on the dilution of the nitrogen in the lung with a known volume of oxygen, complete mixing being ensured by adopting the technique of VAN SLYKE and BINGER [33].

In 1939, two advances occurred that would facilitate the clinical measurement of lung volume. Firstly, HERRALD and MCMichaEL [36] proposed to supply a constant amount of oxygen to the breathing circuit in order to compensate for the oxygen consumption, and to keep constant the volume of the circuit, which makes the calculations easier. An automatically adjusted volume stabilization system was later described by VAN VEen et al. [37]. Secondly, MCMichael [38] introduced the catharometer to easily measure and follow the hydrogen concentration.

In 1940 DARLING et al. [39] substituted on open circuit (washing out progressively the alveolar nitrogen by inspiring pure oxygen) to the closed rebreathing circuit technique for measuring residual air. Their major arguments were the following: 1) the inspiratory gas mixture is always changing and the discrepancies due to poor mixing are not corrected by oxygen replacement; 2 ) the exact calculation of the oxygen absorbed is difficult; 3 ) the net change in the nitrogen concentration is low, so that any error in measurement, results in a large error in calculation.

A major step was accomplished with the replacement of hydrogen with helium by MENEELY and KALTREIDER in 1941 [40]; helium has all the useful properties of hydrogen, but none of its disadvantages. The closed circuit spirometer described by these authors was very similar to the equipment of today, with a blower to homogenize the gas mixtures, soda lime to absorb carbon dioxide, oxygen admission. Two details did however differ from modern procedures: the subject was connected to the spirometer without regard to the phase of respiration, and the rebreathing period was limited to $7 \mathrm{~min}$. Helium was again used by BeHNKE et al. [41] in 1942. In their attempt to determine the specific gravity of the human body, they proposed to measure the residual air by inhaling for a period of $3 \mathrm{~min}$, a helium-oxygen mixture following maximal expiration to remove the residual nitrogen, and subsequently to perform a washout of inhaled helium with $50 \mathrm{~L}$ of air or oxygen. In the mid-1940s, the prolonged dilution of hydrogen during quiet breathing was still used by BIRATH [32], but by the late 1940s the closed circuit helium dilution technique became the standard method. It was further developed by MENEELY and KaLTREIDER [42], and soon adopted by other investigators like BATES and Christie [43], Donald and Christie [44] Gilson and Hugh-Jones [45].

In the mid-1950s, a third method for measuring functional residual capacity, body plethysmograph, was established [26]. An engaging, first hand description of how earlier problems with plethysmography was overcome in Philadelphia has been given by Comroe [46].

The closed circuit prolonged helium dilution, the open circuit nitrogen washout, and the body plethysmograph are, all three, still in use today. Single breath methods have not gained wide acceptance, because they underestimate lung volume in the presence of airflow obstruction, but they were anticipated 200 years ago by Davy, who suggested that hydrogen would diffuse sufficiently rapidly to allow the lung capacity to be measured safely and accurately.

\begin{abstract}
Acknowledgements. The authors thank T. Similowski and J.P. Poirier, for the information they provided about the early experiments on hydrogen by Lavoisier and Seguin, as well as A. Bohadana, C. Laros, R. Peslin, G.J. Tammeling and B. Visser, who contributed to gather the relevant literature. They are particularly grateful to Boehringer, Belgium, that provided copies of nineteenth and early twentieth century German literature.
\end{abstract}

\section{References}

1. Davy H. Researches, chemical and philosophical; chiefly concerning nitrous oxide, or dephlogisticated nitrous air, and its respiration. London, J. Johnson, 1800; pp. 400410.

2. Korns A. A brief history of medical diagnosis. Ann Med Hist 1939; 1: 50-67.

3. Borelli DA. De motu animalium. 2 vol. Rome, Bemabo, 1680-1681.

4. Goodwyn E. The connexion of life with respiration. London, J Johnson, 1788; p. 126.

5. Lundsgaard C, Van Slyke DD. Studies of the lung volume. I. Relation between thorax size and lung volume in normal adults. $J$ Exper Med 1918; 27: 65-85.

6. Bergman NA. The genesis of surgical anesthesia. Park Ridge, Ill: Wood Library Museum of Anesthesiology, 1998.

7. Mitchill SN. Remarks on the gaseous oxyd of azote or of nitrogen and on the effects it produces when generated in the stomach, inhaled into the lungs, and applied to the skin. New York, T and J Swords, 1795.

8. Bergman NA. Samuel Natham Mitchill. A neglected American pioneer of anesthesia. JAMA 1985; 253: 675678.

9. Beddoes T, Watt J. Considerations on the medicinal powers and the production of factitious airs. Bristol, Bulgin and Rosser, 1794-1796.

10. Garrison FH. An introduction to the history of medicine. 2nd ed. Philadelphia, Saunders, 1917.

11. Comroe JH Jr. Retrospectroscope. Flexible minds. Am Rev Respir Dis 1979; 120: 461-469.

12. Gottlieb LS. Thomas Beddoes, MD, and the Pneumatic 
Institution at Clifton, 1798-1801. Ann Intern Med 1965; 63: 530-533.

13. Keys TE. Sir Humphry Davy and his safety lamp for coal miners. Mayo Clin Proc 1968; 43: 865-891.

14. Hutchinson J. On the capacity of the lungs, and on the respiratory functions, with a view of establishing a precise and easy method of detecting disease by the spirometer. Med Chir Trans 1846; 29: 137-252.

15. Gréhant N. Recherches physiques sur la respiration de l'homme. Paris (Imprimerie Martinet): Thèse de Médecine, 1864

16. Séguin A, Lavoisier A. Premier mémoire sur la respiration des animaux. Paris, Mém Acad Sci 1789 (1793); 2: p. 574.

17. Regnault, Reiset. Ann Chimie XXVI, 3è série.

18. Berenstein M. Neue Versuche zur Bestimmung der Residualluft am ledenden Menschen. Arch Ges Physiol 1891; 50: 363-375.

19. Berenstein M. Ein Beitrag zur Bestimmung der Residualluft beim lebenden Menschen. Med Diss: Dorpat, 1891.

20. Tammeling GJ. Het residual volume en de functionele residuaal capaciteit. Assen: Drukkerij Torenlaan, 1958.

21. Rosenblatt MB. Emphysema: historical perspective. Bull NY Acad Med 1972; 48: 823-841.

22. Baldwin E de F, Cournand A, Richards DW Jr. Pulmonary insuffisiency. III. A study of 122 cases of chronic pulmonary emphysema. Med 1949; 28: 201-236.

23. Comroe JH Jr. Retrospectroscope. Man-cans. Am Rev Respir Dis 1977; 116: 945-950.

24. Pflüger E. Das Pneumonometer. Arch Ges Physiol 1882; 29: 244-246.

25. Christie RV. The lung volume and its subdivisions. I. Methods of measurement. J Clin Invest 1932; 11: 10991118.

26. DuBois AB, Botelho SY, Bedell GN, Marshall R, Comroe JH Jr. A rapid plethysmographic method for measuring thoracic gas volume: a comparison with a nitrogen washout method for measuring functional residual capacity in normal subjects. $J$ Clin Invest 1956; 35: 322-326.

27. Durig A. Über die Grösse der Residualluft. Zentralblatt Physiol 1903; 17: 258-267.

28. Schenck F. Ueber die Bestimmung der Residualluft. Arch Ges Physiol 1894; 55: 191-203.

29. Schenck F. Zur Bestimmung der Residualluft. Arch Ges Physiol 1894; 58: 233-241.

30. Bohr C. Die funktionellen Änderungen in der Mittellage und Vitalkapazität der Lungen. Normales und patho- logisches Emphysem. Dtsch Arch klin Med 1907; 88: 385-434.

31. Hasselbach KA. Über die Totalkapazität der Lungen. Arch klin Med 1908; 93: 64-69.

32. Birath G. Lung volumes and ventilation efficiency. Acta Med Scand 1944; Suppl. 154: 1-215.

33. Van Slyke DD, Binger CAL. The determination of lung volume without forced breathing. J Exper Med 1923; 37: 457-470.

34. Anthony A. Untersuchungen über Lungenvolumina und Lungenventilation. Dtsch Arch klin Med 1930; 167: 129176.

35. Knipping HW. Beitrag zur gasanalytischen Tecnik in der Medizin. Zeitschr ges exp Med 1926; 53: 1-9.

36. Herrald FJC, McMichael J. Determination of lung volume: a simple constant volume modification of Christie's method. Proc Roy Soc, London, Ser B 1939; 126: 491501.

37. Van Veen G, Orie NGM, Hirdes JJ. Spirometric lung function investigations. I. A rapid constant-volume method for the determination of the functional residual air. Acta Tuberc Scand 1952; 26: 251-263.

38. McMichael J. Rapid method of determining lung capacity. Clin Sci 1939; 4: 167-173.

39. Darling RC, Cournand A, Richards DW Jr. Studies on the intrapulmonary mixture of gases. III. An open circuit method for measuring residual air. J Clin Invest 1940; 19: 609-618.

40. Meneely GR, Kaltreider NL. Use of helium for determination of pulmonary capacity. Proc Soc Exper Biol \& Med 1941; 46: 266-269.

41. Behnke AR Jr, Feen BG, Welham WC. The specific gravity of healthy men. JAMA 1942; 118: 495-498.

42. Meneely GR, Kaltreider NL. The volume of the lung determined by helium dilution. Description of the method and comparison with other procedures. $J$ Clin Invest 1949; 28: 129-139.

43. Bates DV, Christie RV. Intrapulmonary mixing of helium in health and emphysema. Clin Sci 1949; 9: 17-29.

44. Donald KW, Christie RV. A new method of clinical spirometry. Clin Sci 1949; 8: 21-31.

45. Gilson JC, Hugh-Jones P. The measurement of the total lung volume and breathing capacity. Clin Sci 1949; 7: $185-216$.

46. Comroe JH Jr. Man-Cans (Conclusions). The body plethysmograph (body box). Am Rev Respir Dis 1977; 116: 1091-1099. 